\title{
IMPLEMENTASI ETL DATA WAREHOUSE DENGAN KONSEP FITUR METADATA DAN CLEANSING DATA
}

\author{
${ }^{1}$ I Gusti Ngurah Agung Trisna Putra, ${ }^{2}$ I Nyoman Aditya Mahendra, ${ }^{3}$ I Made Suwija Putra \\ ${ }^{1,2,3}$ Program Studi Teknologi Informasi, Fakultas Teknik, Universitas Udayana, Bali \\ 1,2,3 Jl. Raya Kampus Unud Jimbaran, Kec. Kuta Sel., Kabupaten Badung, Bali 80361, Indonesia \\ Email: gustitrisna@student.unud.ac.id, adityamahendra@student.unud.ac.id, \\ putrasuwija@unud.ac.id
}

(Diterima: 8 Januari 2020, direvisi:16 April 2020, disetujui:24 April 2020 )

\begin{abstract}
The rapid development of technology makes the demand for data processing and presentation needs to be better. Udayana cake shop that sells various types of cakes that are self-produced and have several branches spread across Bali. Udayana cake shop has a problem while analyzing the transaction process due to the large amount of data sent from each branch in a month. The results of this analysis process are used for supporting references in making decisions by store management. The exact method of massive data collection used in analyzing the transaction process is the data warehouse technology approach. Data warehouse supports the ability to do queries decision making, the financial situation, product stocks, and services. The development of this data warehouse uses star scheme modeling and the application of data collection there are stages of ETL (extract, transform, and load) to be able to read data from the OLTP (Online Transaction Processing) system. The design of the system uses OLAP (Online Analytical Processing) to design applications that can collect, store, and manipulate multidimensional data for analysis purposes.
\end{abstract}

Keywords: Star Skema, Data Warehouse, ETL, Python

\begin{abstract}
ABSTRAK
Perkembangan teknologi yang semakin pesat membuat permintaan atas kebutuhan pengolahan dan penyajian data yang lebih baik. Pada toko kue udayana merupakan jenis toko yang menjual berbagai jenis kue yang diproduksi sendiri dan memiliki beberapa cabang yang tersebar di Bali. Toko kue udayana kesulitan dalam menganalisis proses traksaksi dikarenakan banyaknya data yang dikirim dari masing-masing cabang setiap bulannya. Hasil proses analisa ini digunakan untuk acuan pendukung dalam pengambilan keputusan oleh pihak manajemen toko. Metode pengumpulan data massive yang tepat digunakan dalam menganalisis suatu proses transaksi adalah pendekatan teknologi data warehouse. Data warehouse mendukung kemampuan melakukan query untuk mendukung pengambilan keputusan, melihat keadaan finansial, stok produk, dan layanan dengan mudah. Pengembangan data warehouse ini menggunakan pemodelan star skema dan dalam penerapan pengumpulan data ada tahapan ETL (extract, transform, dan load) untuk dapat membaca data dari sistem OLTP (Online Transaction Processing). Perancangan pada sistem menggunakan OLAP (Online Analytical Processing) untuk mendesain aplikasi yang bisa mengumpulkan, menyimpan, serta memanipulasi data multidimensi sebagai tujuan analisis.
\end{abstract}

Kata Kunci: Star Skema, Data Warehouse, ETL, Python

\section{PENDAHULUAN}

Berkembangnya teknologi dan informasi saat ini semakin pesat sehingga menghasilkan kumpulan data yang besar. Kumpulan data besar dapat diimplementasikan disuatu DBMS (Database Management System) yang nantinya diolah untuk mendapatkan kebutuhan informasi yang cepat, akurat dan menjadi suatu informasi yang lebih berguna[1]. Toko Kue Udayana merupakan jenis toko kue yang menjual berbagai jenis kue yang diproduksi sendiri. Toko ini memiliki beberapa cabang yang tersebar di Bali sehingga kesulitan dalam menganalisis transaksi disetiap cabang yang ada untuk pengambilan keputusan. Sistem operasional pada toko kue ini masih terbatas sehingga dalam pembuatan laporan akhir setiap penjualan dimasing-masing cabang masih konvensional. Proses 
pengambilan data transaksi dari masing-masing cabang ke toko pusat masih menggunakan email atau sms. Hal ini menyebabkan tidak adanya sinkronisasi data dari toko cabang dan toko pusat.

Perkembangan teknologi dalam bidang informasi terus berkembang dan kebutuhan masyarakat yang meningkat, sehingga menimbulkan permintaan dalam hal penyajian data dalam bentuk laporan penjualan pada suatu perusahaan. Solusi yang diberikan yaitu dengan menerapkan teknologi data warehouse untuk pengumpulan data transaksi yang bersifat historis dan disimpan secara terstruktur dalam sebuah data warehouse. Data warehouse merupakan sumber informasi yang diharapkan dapat membantu dalam pengambilan keputusan bisnis yang tepat[2].

Penggunaan data warehouse pada perusahaan bertujuan membantu proses penyimpanan dan penyajian data sehingga perusahan dapat mencatat segala transaksi yang terstruktur. Penerapan data warehouse merupakan tempat untuk sinkronisasi data yang didalamnya terjadi penyamaan struktur data sehingga data transaksi dapat diterima pada data warehouse. Proses sinkronisasi didalam data warehouse atau disebut dengan proses ETL (extract, transform, dan load) yang menjembatani antara data transaksi dengan media penyimpanan data warehouse [3].

ETL merupakan sekumpulan proses mengumpulkan, menyaring, mengolah, dan menggabungkan data yang harus dilalui dalam pembentukan data warehouse. Proses ETL ini terdiri dari proses Extracting, tranforming, dan loading. Extracting adalah proses memilih dan mengambil data dari suatu kumpulan data sebuah perusahaan. Tranforming merupakan proses membersihkan dan mengubah struktur data dari bentuk asli menjadi bentuk yang sesuai dengan kebutuhan data warehouse. Load merupakan proses terakhir yang berfungsi untuk memasukan data kedalam data warehouse [4].

Dalam data warehouse diperlukan database metadata untuk mendeskripsikan data, definisi masing-masing tabel, struktur penyimpanan data dan proses ETL. Metadata diperlukan didalam data warehouse karena untuk menggambarkan dan menjelaskan data dan gudang data baik struktur dan prosesnya untuk mempermudah pengguna. Metadata dapat membantu pengguna dalam penggunaan data warehouse dalam meningkatkan dan memelihara data warehouse. Definisi data didalam metadata membantu menghindari kesalahpahaman dalam makna kolom tertentu [5].

Penelitian sebelumnya mengenai penerapan teknologi data warehouse di sebuah perguruan tinggi yang dilakukan oleh Yetli Oslan dan Harianto Kristanto dengan judul Proses ETL Data Warehouse Untuk Peningkatan Kinerja Biodata Dalam Menyajikan Profil Mahasiswa Dari Dimensi Asal Sekolah [6]. Data warehouse yang dibangun menggunakan proses ETL manual dan terdapat proses cleaning data yang masih secara manual.

Oleh karena itu penelitian ini mencoba membangun engine ETL yang bekerja automatic dengan basis metadata dan cleaning data menggunakan bahasa python. Bahasa python yang bersifat open source sehingga bisa menyesuaikan dengan kebutuhan perusahaan dengan tampilan OLAP yang dapat membantu dalam pengambilan keputusan. Proses engine ETL bisa dilakukan secara manual dan otomatis yang dapat ditentukan rentang waktunya.

\section{TINJAUAN PUSTAKA}

Pada saat akan melakukan suatu penelitian maka hal yang paling utama yang dibutuhkan ialah sebuah dukungan dari setiap hasil dari setiap penelitian yang sebelumnya memang sudah ada dan masih saling berkaitan dengan hasil dari penelitian tersebut.

Berdasarkan penelitian dari Made Pradnyana Ambara (2016) dari jurnalnya yang berjudul "Desain Sistem Semantic Data Warehouse dengan Metode Ontology dan Rule Based untuk Mengolah Data Akademik Universitas XYZ di Bali" mengungkapkan perancangan sebuah data warehouse dengan menggunakan snowflake schema. Namun pada pengimplementasian aplikasi OLTP (Online Transaction Processing) yang dibangun masih kurang memadai karena data warehouse yang dibangun menggunakan proses ETL (Extract, Transform, dan Load) yang masih melibatkan administrator sebagai operator yang mengerjakan proses kerja ETL atau menjadwalkan proses ETL. Jadi pada penelitian memiliki kelebihan yakni dibuatkan ETL yang dapat berjalan secara otomatis[7].

Sedangkan dari penelitian Dewa Komang Tri Adhitya Putra (2019) dari jurnalnya yang berjudul "Rancang Bangun Engine ETL Data Warehouse dengan Menggunakan Bahasa Python" mengemukakan engine ETL data warehouse yang sudah menerapkan cleansing data namun belum terdapat metadata dari sistem yang dibangun. Metadata merupakan data yang mendeskripsikan data 
lebih detail saat digunakan disuatu data warehouse. Fitur metadata ini berguna untuk user manual agar mengetahui tabel asal dan tabel tujuan dalam melakukan proses extrat pada sebuah sistem. Sehingga pada penelitian ini dibuatkan metadata dalam merancang dan membangun data warehouse[8].

\section{METODE PENELITIAN}

Metode yang digunakan dalam perancangan data warehouse ini yaitu metode waterfall. Metode waterfall merupakan pendekatan klasik dalam pengembangan perangkat lunak yang menggambarkan metode pengembangan linier dan berurutan. Penelitian diawali dengan mengidentifikasi masalah yang ditemukan, kemudian data dikumpulkan dan mendesain arsitektur database. Tahapan selanjutnya mendesain mesin ETL dan sistem OLAP menggunakan bahasa HTML yang kemudian dilakukan pengujian terhadap sistem yang sudah dibangun. Tahapan terakhir adalah dokumentasi dalam pembuatan laporan sistem. Alur penelitian sebagaimana dapat dilihat pada gambar 1 .

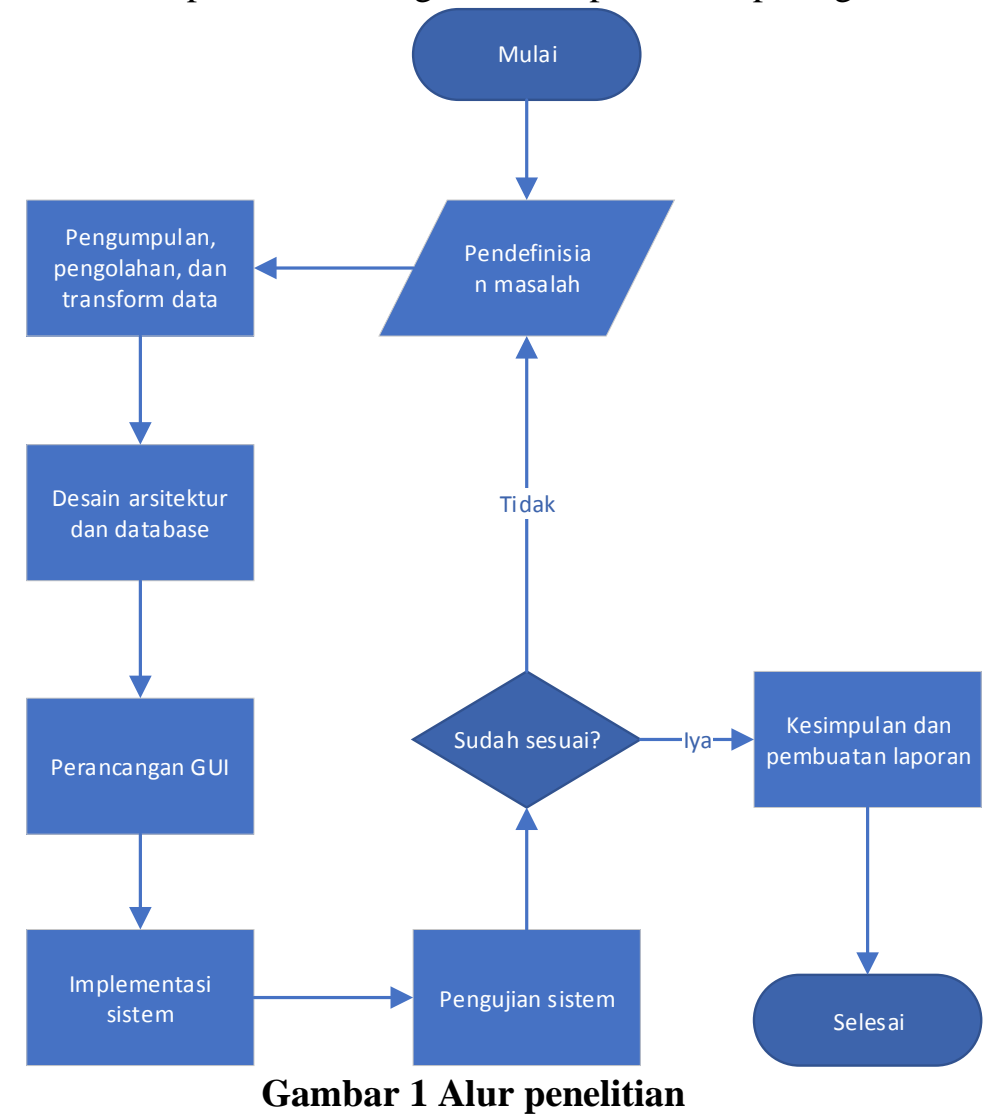

Gambar 1 merupakan alur penelitian yang digunakan dalam pengerjaan penelitian ini. Dimulai dari tahap pendefinisian masalah yang menentukan studi kasus yang akan diangkat didalam penelitian. Tahap pengumpulan, pengolahan dan transform data untuk selanjutnya dibuat desain arsitektur dan database. Tahap perancangan GUI, tahap ini dilakukan perancangan sistem engine ETL yang kemudian di implementasikan dalam bentuk OLAP (Online Analytical Processing).

\subsection{Gambaran Umum Sistem}

Studi kasus yang diangkat pada ETL ini adalah kasus toko kue. Tahapan dalam proses ETL dimulai dari inisiliasi database dan menjadikan data yang bisa dianalisis sesuai kebutuhan user. Gambaran umum sistem dapat dilihat pada gambar 2. 


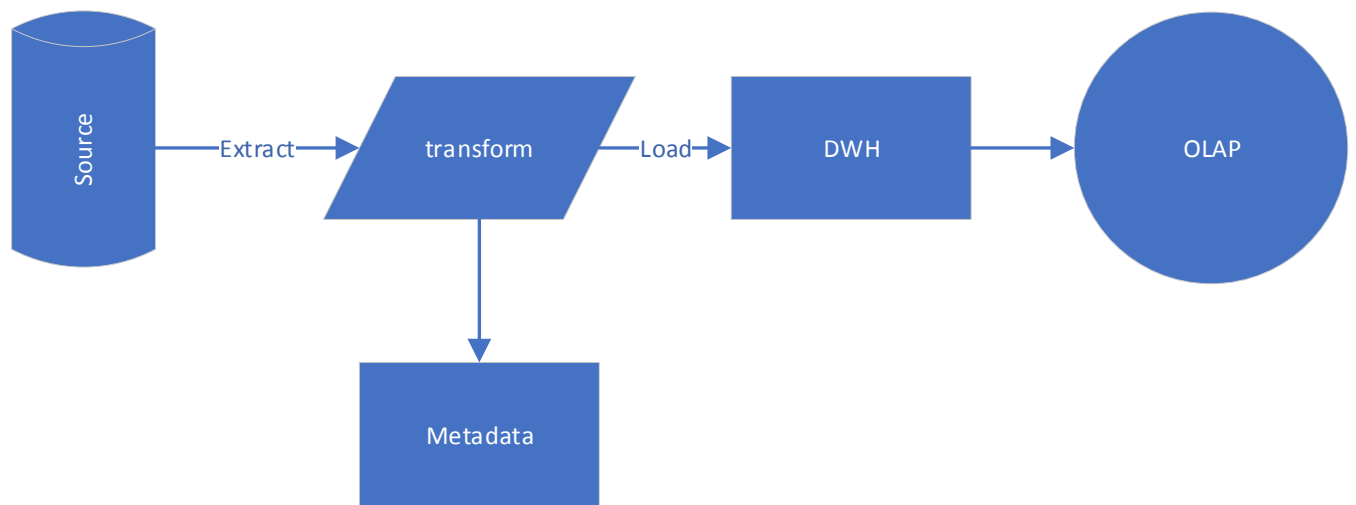

Gambar 2 Gambaran umum sistem

Gambar 2 merupakan gambaran umum sistem yang digunakan dalam melakukan penelitian ini. Sumber data OLTP yang digunakan berasal dari database db_toko yang kemudian dilakukan proses extract dan transform seluruh data di OLTP. Didalam proses ETL terdapat proses penyamaan struktur data dan proses cleansing data yang berfungsi untuk menghilangkan duplikat data guna menghasilkan data yang lebih berkualitas. Data yang sudah melalui proses cleansing kemudian di load dan disimpan menuju database db_tokokue yang merupakan database data warehouse.

\subsection{Rancangan Skema OLTP}

Data transaksi pada database OLTP menyimpan secara keseluruhan data transaksional pembelian dan penjualan pada toko kue udayana, dimana konsep yang digunakan adalah konsep relasional databse. Pada rancangan database OLTP terdapat 9 tabel yang memiliki fungsi tersendiri dan saling berhubungan. Rancangan skema OLTP dapat dilihat pada gambar 3.

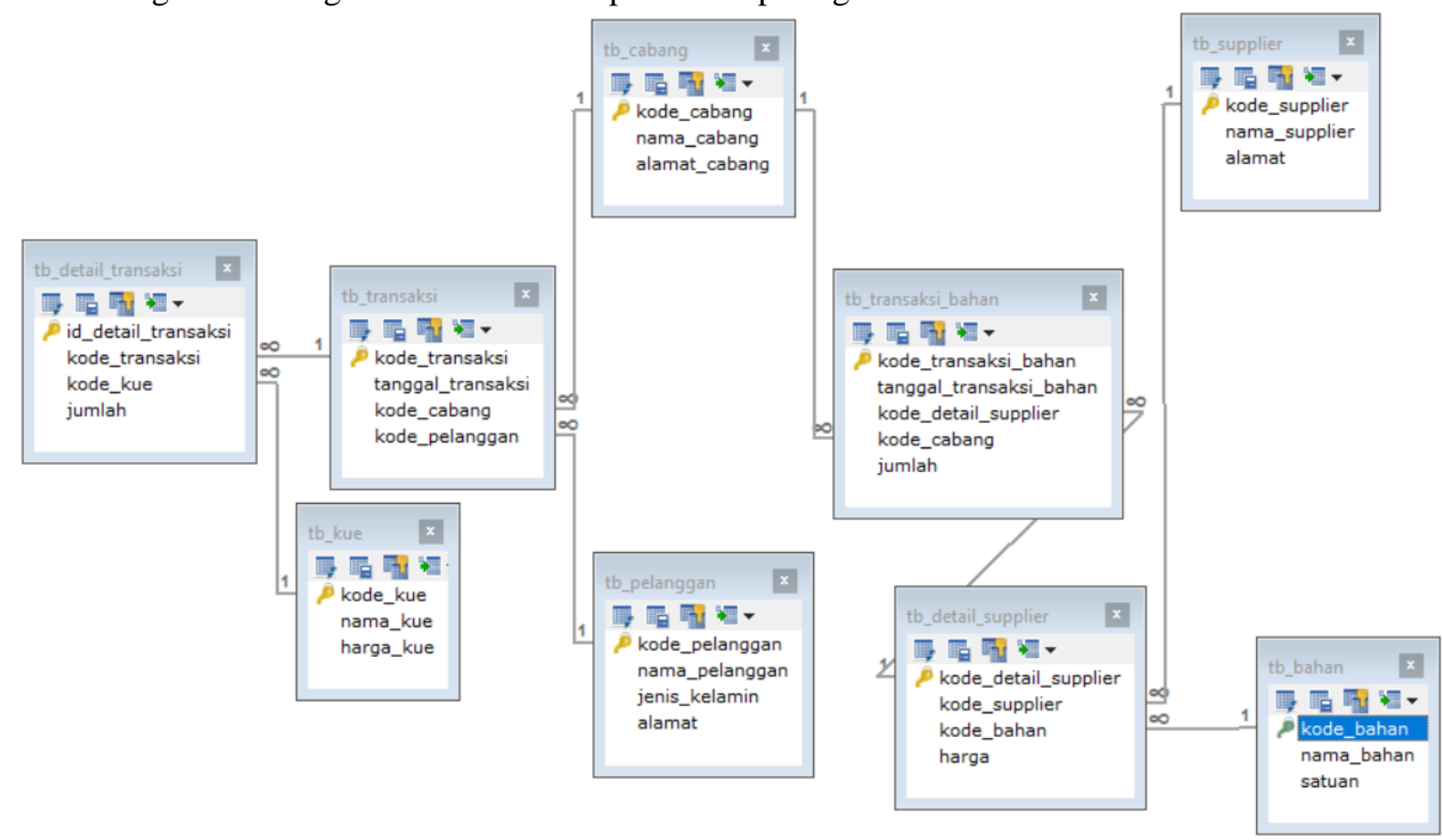

\section{Gambar 3 Rancangan skema OLTP}

Gambar 3 merupakan rancangan skema OLTP yang terdapat 9 tabel didalamnya, diantaranya tabel transaksi berfungsi untuk menyimpan transaksi penjualan, tabel detail transaksi berfungsi untuk menyimpan transaksi secara lebih detail, tabel kue berfungsi untuk menyimpan data kue, tabel pelanggan berfungsi untuk menyimpan data pelanggan, tabel cabang berfungsi untuk menyimpan data nama dan alamat cabang, tabel transaksi bahan berfungsi untuk menyimpan transaksi bahan, tabel 
supplier berfungsi untuk menyimpan data supplier, tabel detail supplier berfungsi untuk menyimpan data supplier secara lebih detail, dan tabel bahan berfungsi untuk menyimpan data bahan.

\subsection{Rancangan Skema Data Warehouse}

Data dari proses OLAP tersebut akan tersimpan pada database data warehouse. Rancangan database data warehouse ini dibangun dengan menggunakan star skema. Skema tersebut terdiri dari tabel fakta dan tabel-tabel dimensi yang terhubung dengan tabel fakta. Terdapat 2 tabel fakta yaitu tabel fakta penjualan dan tabel fakta supply, dan 6 tabel dimensi yaitu dimensi kue, dimensi waktu, dimensi pelanggan, dimensi cabang, dimensi supplier, dan dimensi bahan. Rancangan skema data warehouse dapat dilihat pada gambar 4.

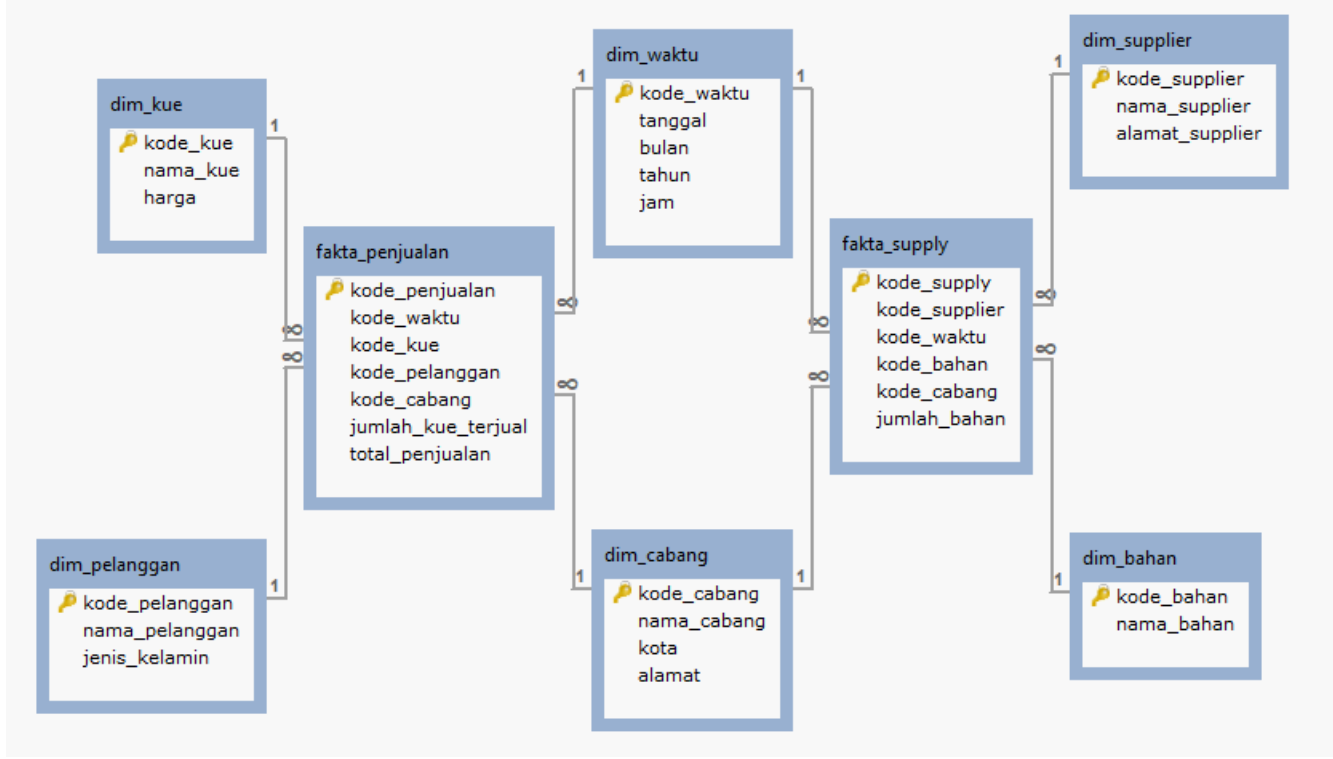

Gambar 4 Rancangan skema data warehouse

Gambar 4 merupakan rancangan skema data warehouse berisikan tabel fakta_penjualan terdapat beberapa field diantaranya kode_penjualan, kode_waktu, kode_pelanggan, kode_cabang, jumlah_kue_terjual, total_penjualan yang berelasi antar tabel dimensi lainya. Pada tabel fakta_supply terdapat field-field diantaranya kode_supply, kode supplier, kode_waktu, kode_bahan, kode_cabang, jumlah_bahan yang berelasi antar tabel dimensi lainnya. Tabel fakta_penjualan tabel fakta_supply berfungsi untuk menampung semua data yang berelasi agar mempermudah dalam pemanggilan isi data didalam tabelnya.

\subsection{Rancangan Skema Metadata}

Rancangan database metadata merupakan database yang berisikan deskripsi atau penjelasan dari kegunaan suatu tabel. Didalam database metadata ini terdapat 6 tabel diantaranya tb_field_dbkue, tb_master_kue, tb_mappinng_field, tb_mapping_tabel, tb_master_tokokue, tb_field_dbtokokue, to_riwayat dan tb_detäil_riwayat. 


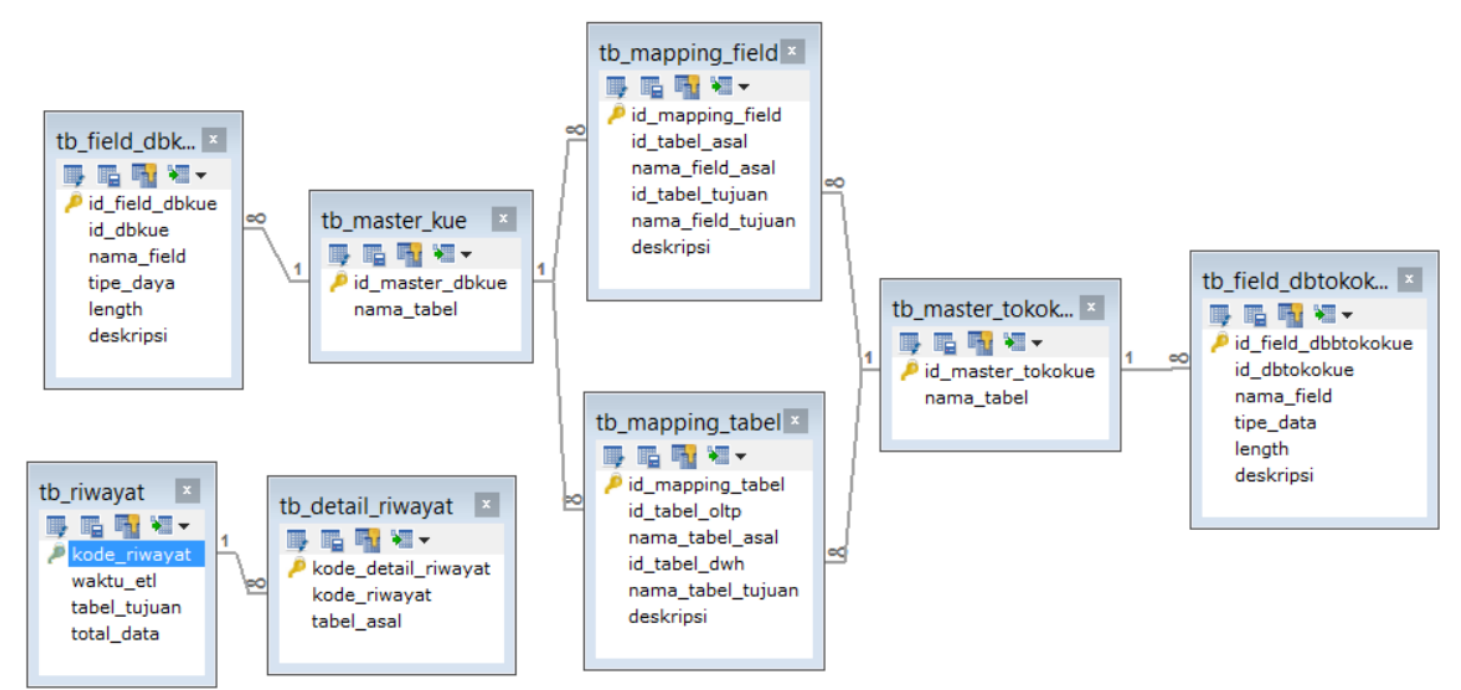

Gambar 5 Rancangan skema metadata

Gambar 5 merupakan rancangan skema metadata yang berisikan tabel tb_mapping_field terdapat beberapa field diantaranya id_mapping_field, id_tabel_asal, nama_field_asal, id_tabel_tujuan, nama_field_tujuan, deskripsi yang berelasi antar tabel lainya. Pada tb_mapping_tabel terdapat field-field diantaranya id_mapping_tabel, id_tabel_oltp, nama_tabel_asal, id_tabel_dwh, nama_tabel_tujuan, deskripsi yang yang berelasi antar tabel dimensi lainnya. Tabel tb mapping_field tabel tb mapping_tabel berfungsi untuk menampung semua data yang berelasi agar mempermudah dalam pemanggilan isi data didalam tabelnya. Pada dua tabel utama ini menjelaskan metadata tentang tabel apa saja yang ada di toko kue, alur jalannya data dari database OLTP ke dalam database DWH. Untuk mempermudah dalam mencari informasi database db_metadata_tokokue juga sudah dilengkapi dengan deskripsi pada setiap tabelnya. Pada db_metadata_tokokue juga terdapat tb_riwayat dan tb_detail_riwayat untuk menyimpan kapan, tabel asal dan tabel tujuan dan total data yang berhasil dilakukan ETL pada engine ETL toko kue ini.

\section{HASIL DAN PEMBAHASAN}

Hasil dari penelitian ini merupakan implementasi ETL dan pengujian OLAP yang telah dirancang pada pembahasan sebelumnya dengan tujuan agar engine ETL dan tampilan OLAP dapat bekerja sesuai kebutuhan. Proses ETL bekerja dengan 2 cara yaitu dengan proses manual ETL dan proses Automatic ETL yang bekerja sesuai dengan penjadwalan yang ditentukan. Pada kedua proses ini sudah dilengkapi dengan proses cleansing data agar nantinya data inputan pada OLAP sudah data yang sudah sesuai dengan yang di inginkan dalam menunjang kebutuhan pengambilan keputusan.

\subsection{Cleansing Data}

Proses pemasukkan data yang sudah terlanjur ada dalam database masih dapat dibersihkan (cleansing) dengan konsep yang dibahas pada jurnal ini. Secara garis besar kualitas data dapat dilakukan atas inisiatif dari beberapa pemeran/role. Proses cleansing dalam penelitian ini difokuskan pada pembersihan nama kue yang sangat terbuka untuk terjadinya kesalahan saat pemasukkan data. Hal ini ini disebabkan karena antar muka yang digunakan saat input berupa text box, dan tipe data yang masuk ke database merupakan varchar, seperti terlihat pada Gambar 6. 


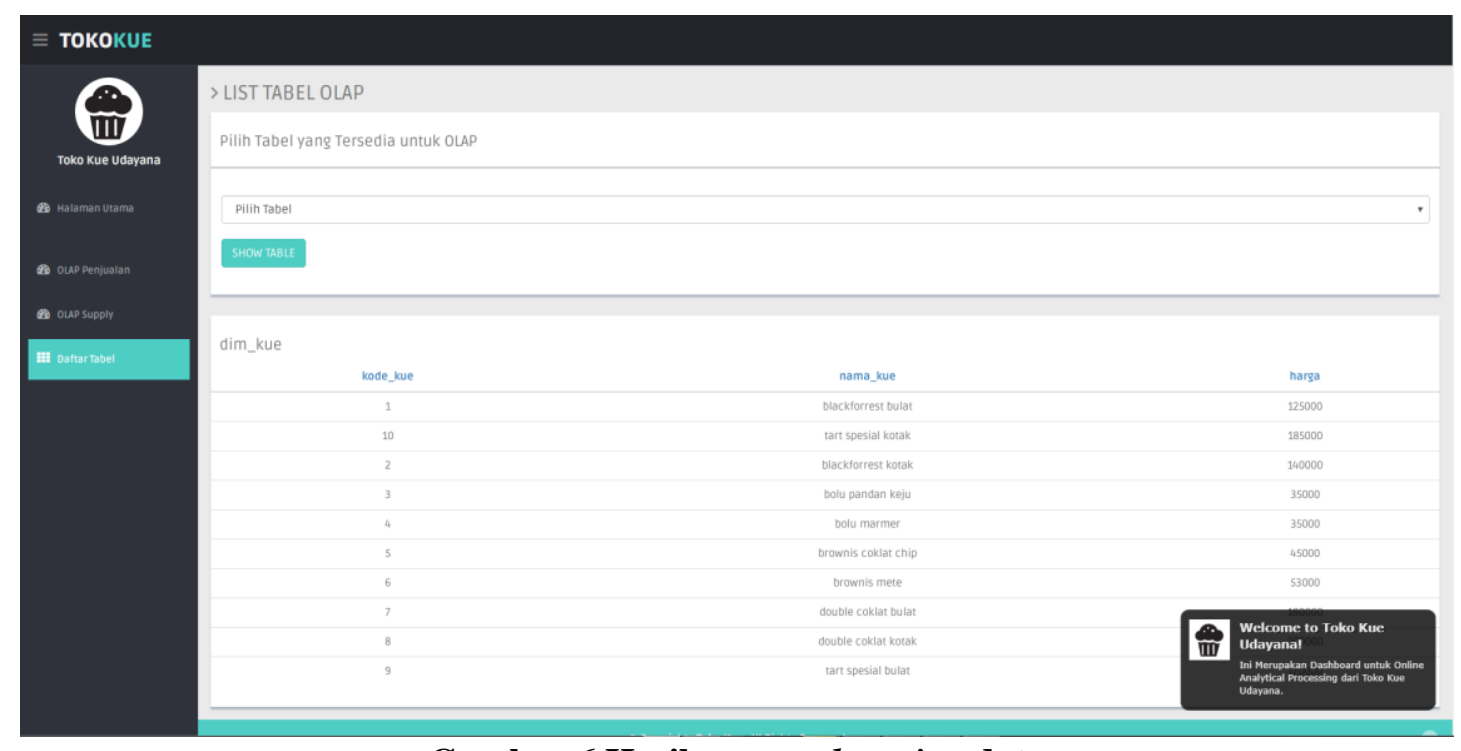

Gambar 6 Hasil proses cleansing data

Gambar 6 merupakan gambar hasil dari proses cleansing data yang terjadi pada Data Warehouse Toko Kue. Proses cleansing atas data dilakukan dengan langkah-langkah mengumpulkan data kue yang di inputkan, lalu melalui proses cleansing data, setelah data di extract maka data hasil transform ke database data warehouse akan sama seperti nama kue yang benar yang telah ditentukan. Dalam proses cleansing ditemukan beberapa kendala yang dapat diselesaikan secara tuntas, melalui langkahlangkah di atas. Namun, ada juga yang tidak dapat diselesaikan karena harus mencari dokumen manual atau bertanya kepada yang bersangkutan.

\subsection{Fitur Metadata}

Metadata pada Toko Kue berfungsi untuk mendeskripsikan data, mendefinisikan objek-objek yang terdapat pada masing-masing tabel yang ada pada Toko Kue. Pada fitur show tabel metadata ini dapat menampilkan data suatu tabel secara lebih detail seperti id, nama field, tipe data, length, dan deskripsi. Fitur metadata ini berguna untuk user manual agar mengetahui tabel asal dan tabel tujuan dalam melakukan proses extrat pada Toko Kue. Pada fitur ini juga sudah dilengkapi dengan field deskripsi yang menjelaskan fungsi tabel, fungsi field pada tabel, relasi yang terjalin antar tabel, serta relasi yang tejalin antara field yang ada. Pada fitur ini juga user dapat mengetahui field mana saja yang akan dilakukan proses ETL ke dalam database data warehouse Toko Kue. List table metadata sebagaimana gambar 7 .

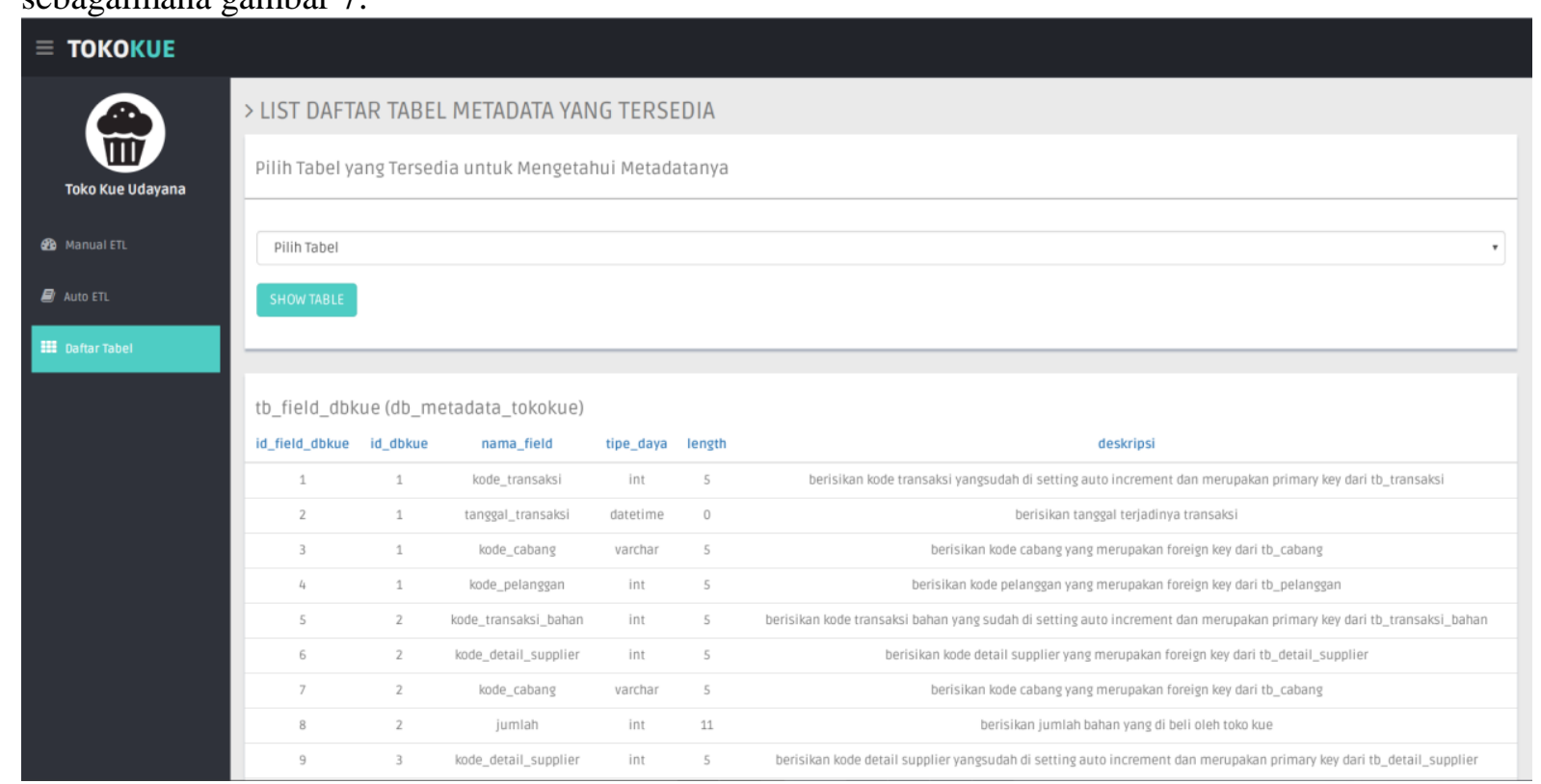

Putra, Implementasi ETL Data Warehouse Dengan Konsep Fitur Metadata Dan Cleansing Data Pada Toko Kue 


\section{Gambar 7 List tabel metadata}

Pada Gambar 7 List Tabel Metadata menunjukan metadata dari semua tabel yang ada pada database OLTP. Pada tabel metadata dapat menjelaskan tipe data dan deskripsi suatu tabel field yang ada pada database OLTP.

\subsection{Fitur Manual ETL}

Proses manual ETL merupakan cara yang digunakan untuk menjalankan proses ETL secara manual yang artinya proses ini berjalan ketika user menjalankan service yang ada pada ETL. Tampilan interface pada manual ETL dapat dililhat pada gambar 8 berikut.

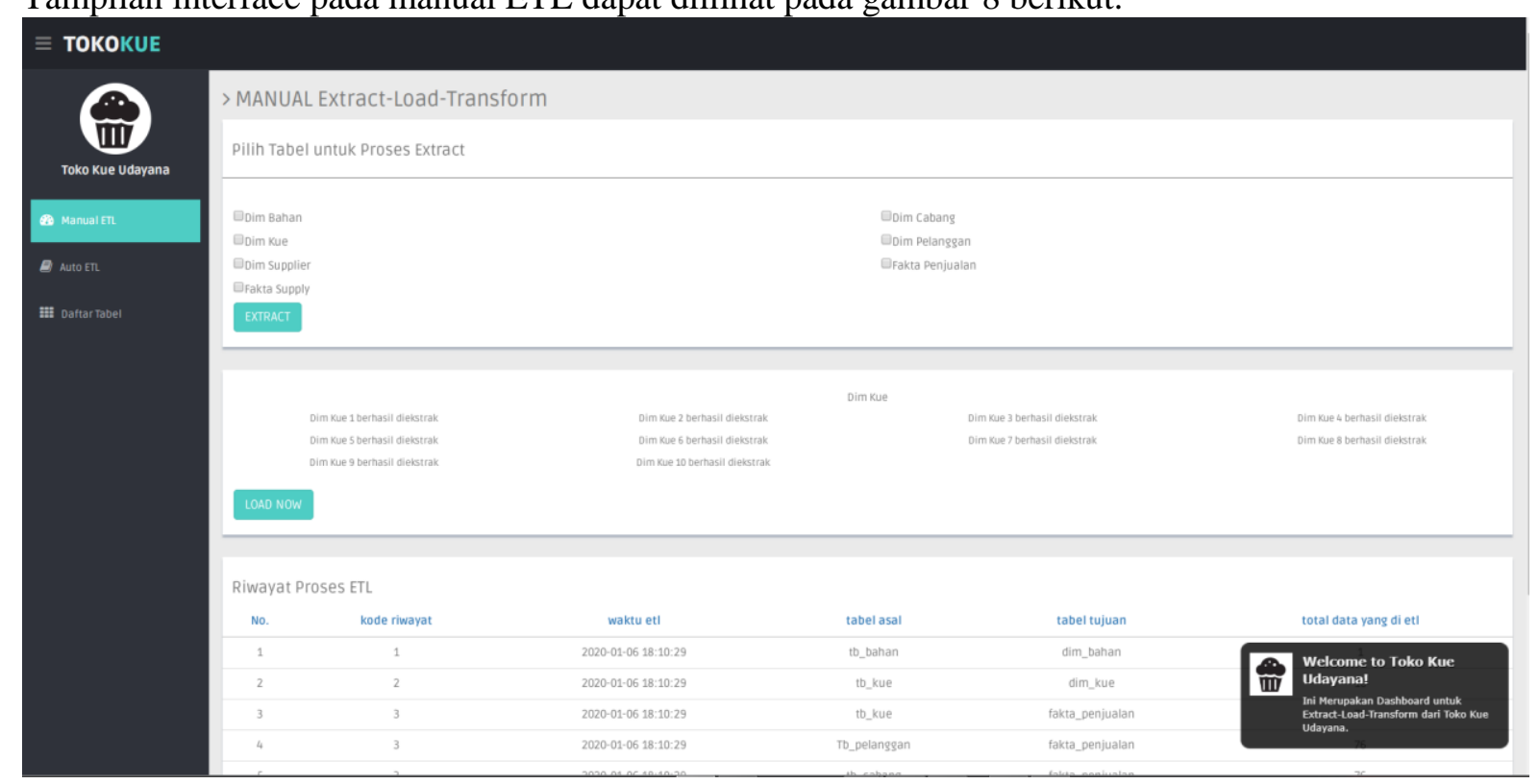

Gambar 8 Tampilan manual ETL

Pada tampilan manual ETL terdapat beberapa checkbox untuk memilih dimensi apa saja yang ingin di extract kedalam data warehouse. Jika checkbox yang dipilih terdapat data baru, maka akan muncul data baru serta kode dari checkbox yang akan di extract. Apabila user akan melanjutkan proses ETL maka dapat menekan button ' $L O A D N O W$ ' untuk melakukan proses load kedalam tabel data warehouse. Kemudian setelah proses extract dan load selesai terdapat riwayat proses ETL yang menunjukan data apa saja yang telah masuk kedalam warehouse, informasi mengenai tabel asal dan tabel tujuan dari proses ETL, menampilkan kapan proses ETL dilakukan serta total banyak data yang di ETL ke dalam data warehouse. 


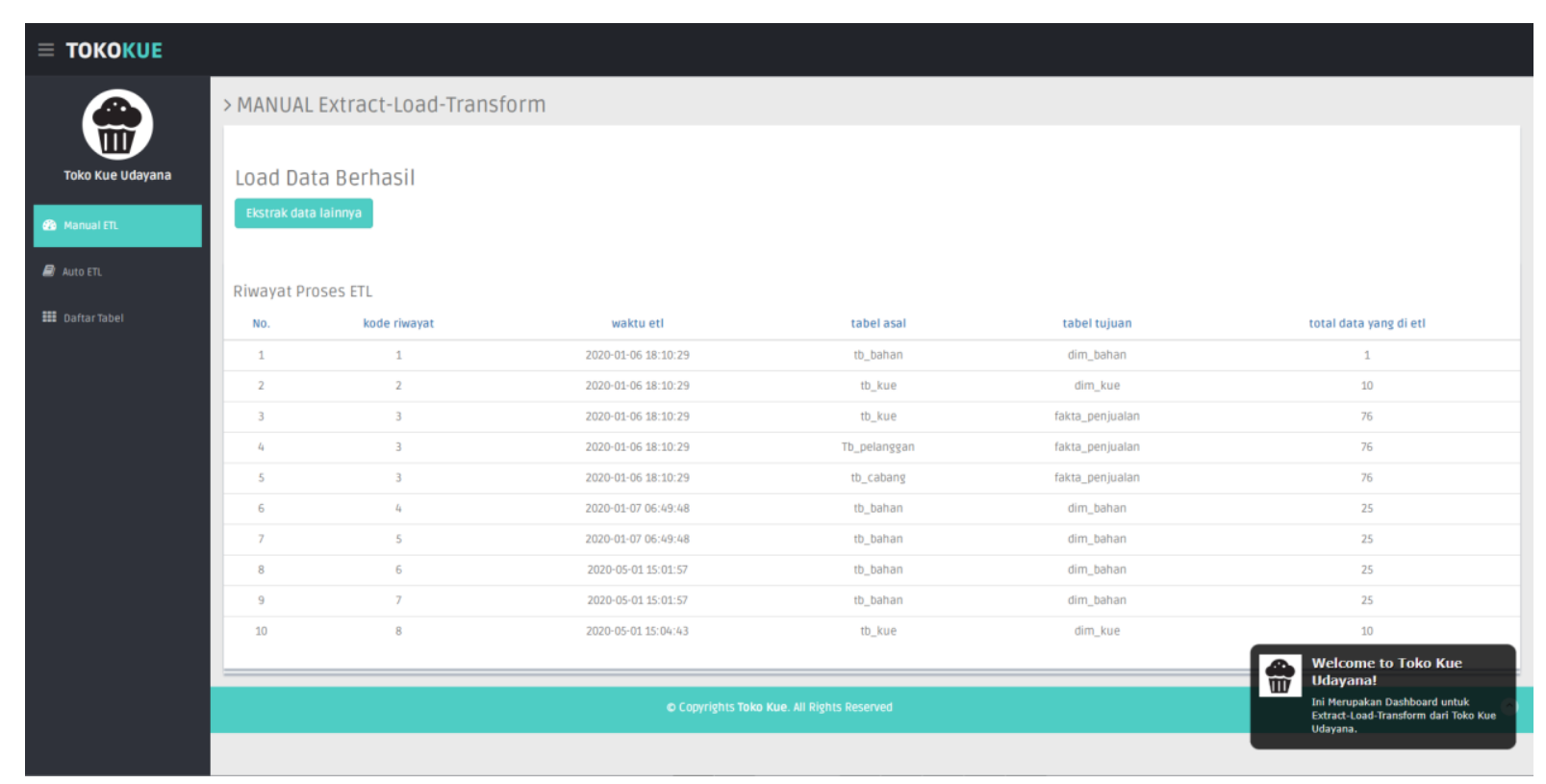

\section{Gambar 9 Tampilan ETL jika berhasil}

Pada tampilan manual ETL ini menampilkan jika proses extract data berhasil dan dilanjutkan dengan load data. Dapat dilihat juga pada gambar 9 riwayat proses ETL bertambah karena sudah dilakukannya proses ETL pada engine.

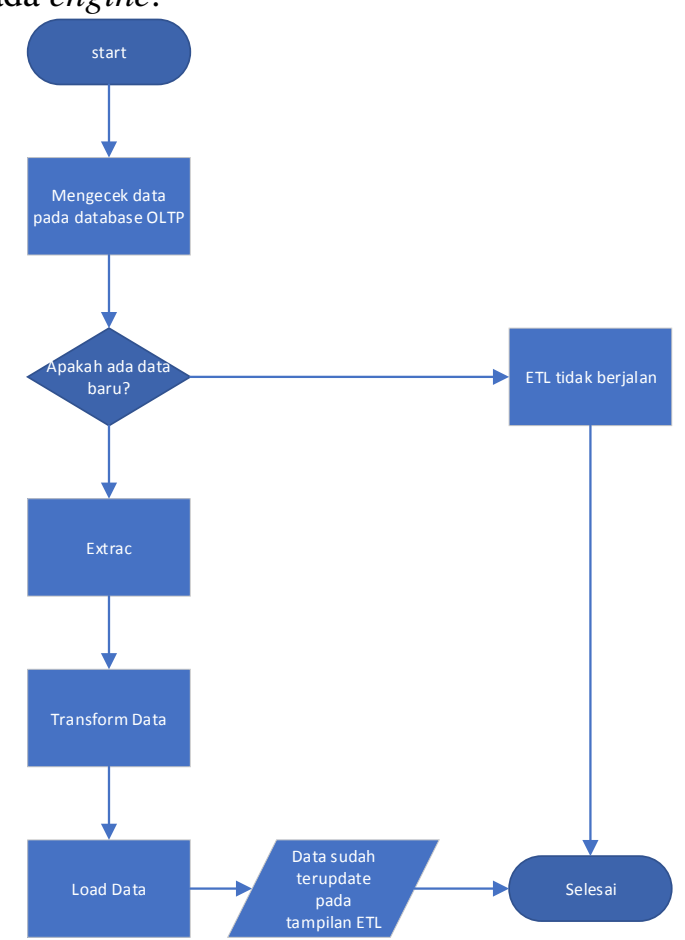

Gambar 10 Flowchart manual ETL

Gambar 10 merupakan flowchart manual ETL yang dimulai dari mengecek data pada database OLTP. Tahap berikutnya jika terdapat data baru maka proses ETL akan berjalan yang kemudian disimpan pada data warehouse, jika tidak maka proses ETL tidak berjalan.

\subsection{Fitur Automatic ETL}

Proses Automatic ETL merupakan cara yang digunakan untuk menjalankan ETL secara lebih efisien tanpa harus ada user yang menjalankan service secara manual. Proses Automatic ETL akan menjalankan proses extract data, transform data, dan load data secara otomatis dengan mengatur waktu (hari) maka proses ETL berjalan sesuai hari yang diinginkan.

Putra, Implementasi ETL Data Warehouse Dengan Konsep Fitur Metadata Dan Cleansing Data Pada Toko Kue 


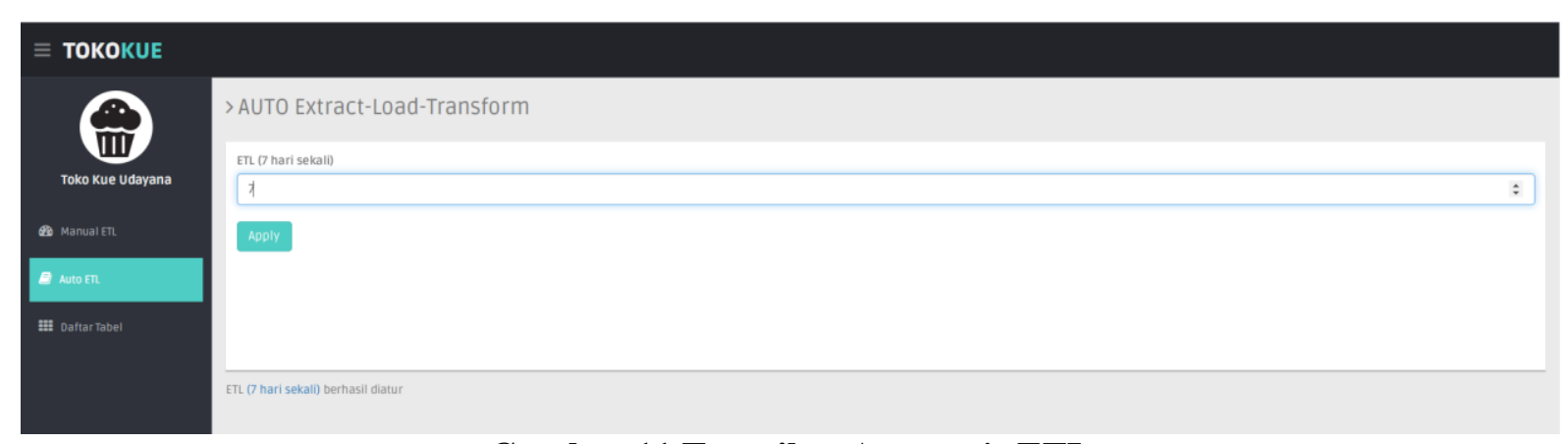

Gambar 11 Tampilan Automatic ETL

Gambar 11 merupakan tampilan dari fitur Automatic ETL yang ada pada Toko Kue. Terdapat input tipe number untuk menentukan ETL akan otomatis dilakukan setiap berapa hari sekali. Setelah dilakukan setting, proses ETL pada Toko Kue akan otomatis dilakukan sesuai dengan yang diinginkan user.

\subsection{Hasil Sistem OLAP}

Penelitian ini membangun sistem analisa data didalam data warehouse disebut OLAP (Online Analytical Processing) yang ditujukan untuk manajemen level atas didalam sebuah perusahaan yang bertujuan untuk membantu dalam pengambilan keputusan. Sistem OLAP ini menyediakan berbagai jenis laporan seperti laporan penjualan dan pembelian barang pada bulan atau tahun tertentu didalam bentuk grafik dan tabel.

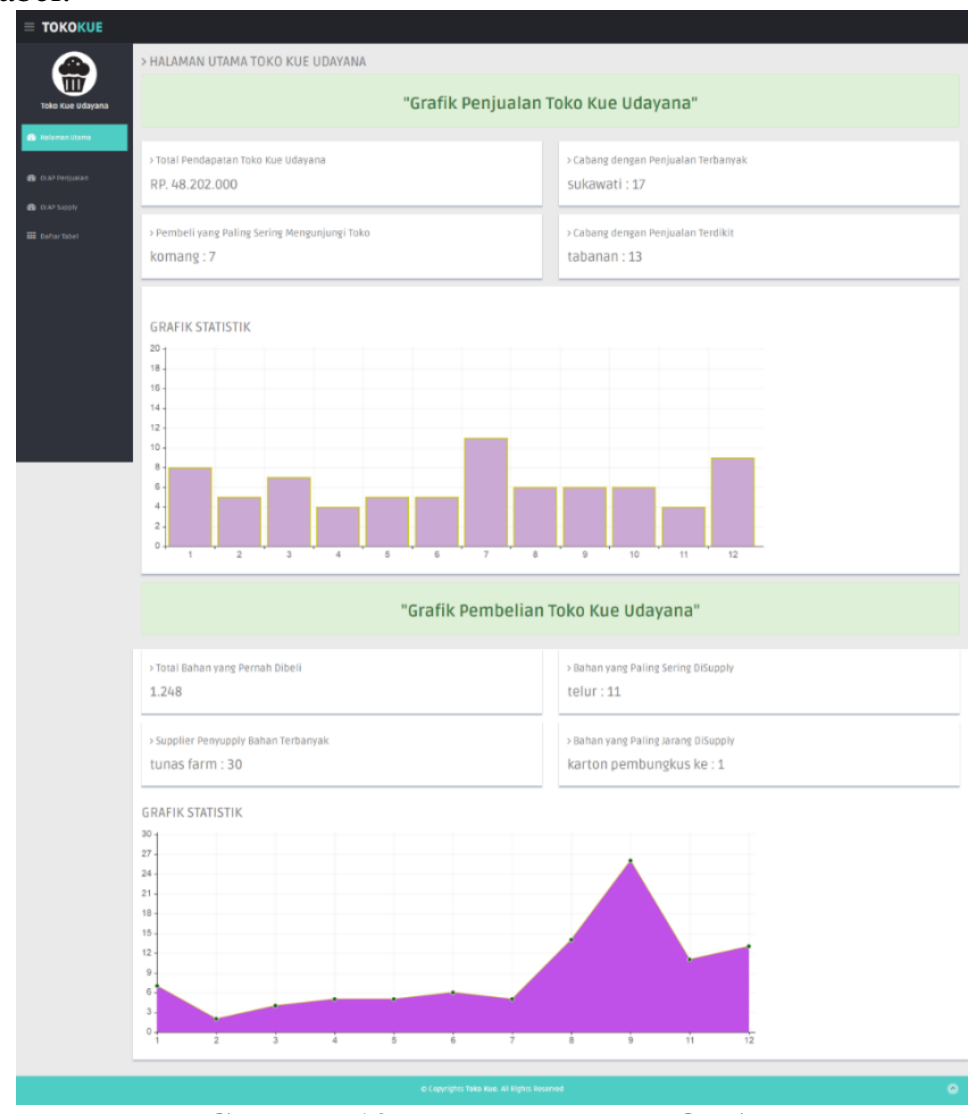

Gambar 12 Halaman utama OLAP

Gambar 12 merupakan halaman utama OLAP yang menampilan grafik penjualan dan grafik pembelian dari toko kue udayana. Pada tampilan grafik penjualan toko kue udayana ini berisikan informasi pendapatan toko, cabang dengan penjualan terbanyak, cabang dengan penjualan terdikit dan nama pembeli yang paling sering mengunjungi toko serta sudah dilengkapi grafik batang untuk memudahkan dalam proses analytical. Pada tampilan grafik pembelian toko kue udayana ini ini 
terdapat total bahan yang dibeli, barang yang paling sering dibeli, supplier terbanyak, dan barang yang paling jarang di supply serta sudah dilengkapi grafik batang untuk memudahkan dalam proses analytical.

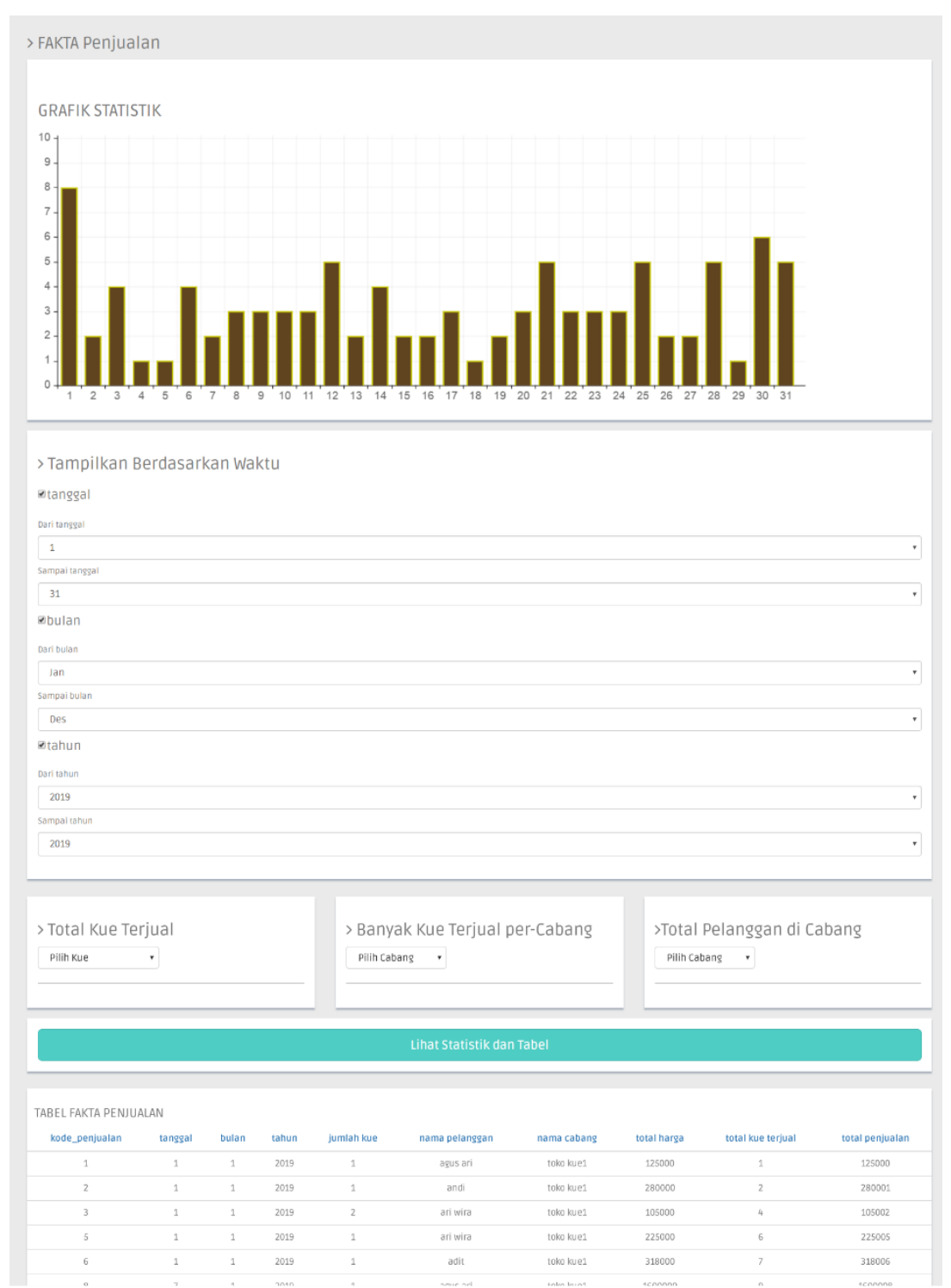

\section{Gambar 13 Tampilanf Filter waktu pada OLAP penjualan}

Gambar 13 merupakan tampilan filter waktu yang menampilkan grafik penjualan berdasarkan filter waktu (tanggal, bulan dan tahun) pada screenshot ditampilakan hasil penjualan toko kue dari tanggal 1 hingga 31 pada semua bulan dan semua tahun. 


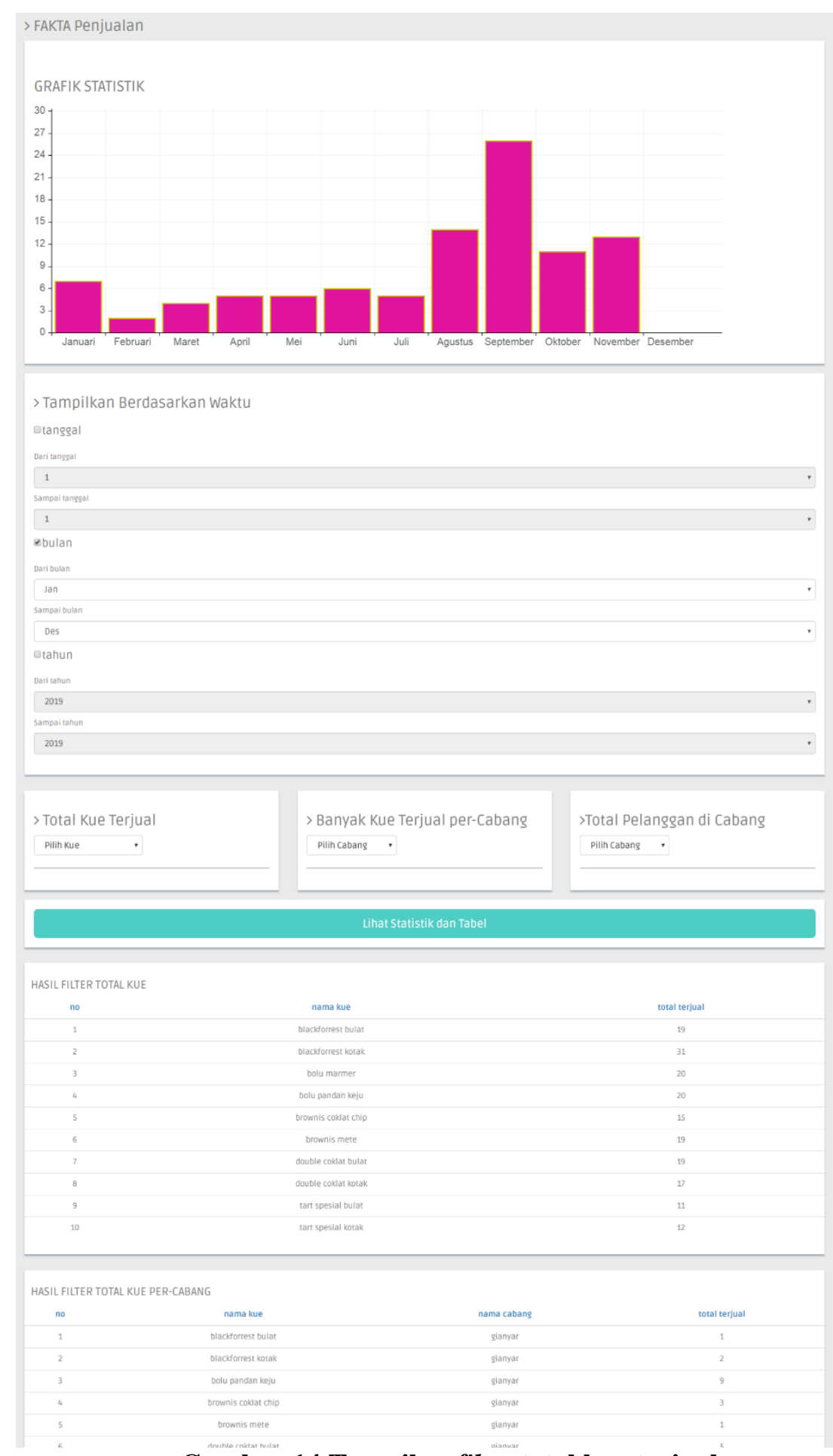

Gambar 14 Tampilan filter total kue terjual

Gambar 14 merupakan tampilan filter total kue terjual pada semua cabang berdasarkan filter waktu bulan Januari hingga Desember. Terdapat juga dua filter lainnya yaitu banyak kue terjual percabang dan filter total pelanggan di setiap cabang, ketiga filter dapat juga digabungkan dengan filter waktu sesuai dengan kebutuhan analytical. Ketiga fitur filter pada olap penjualan ini jika sudah menekan tombol 'lihat statistik dan tabel' akan menampilan dalam bentuk grafik pada bagian atas dan dalam bentuk tabel pada bagian bawah filter. 


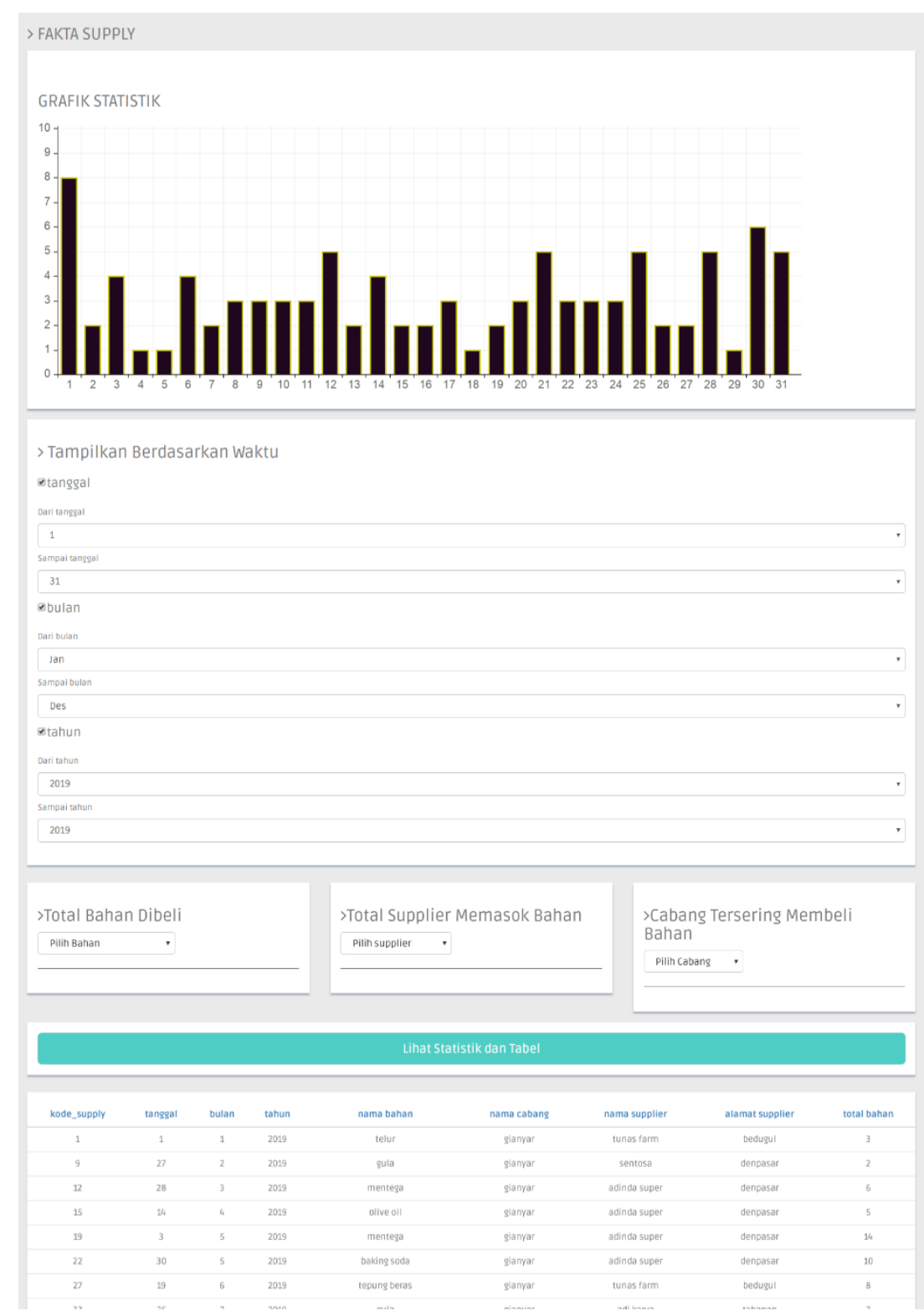

Gambar 15 Tampilan filter waktu pada OLAP supply

Gambar 15 merupakan tampilan filter waktu yang menampilkan grafik pembelian berdasarkan filter waktu (tanggal, bulan dan tahun) pada screenshot ditampilakan hasil pembelian toko kue dari tanggal 1 hingga 31 pada semua bulan dan semua tahun. 


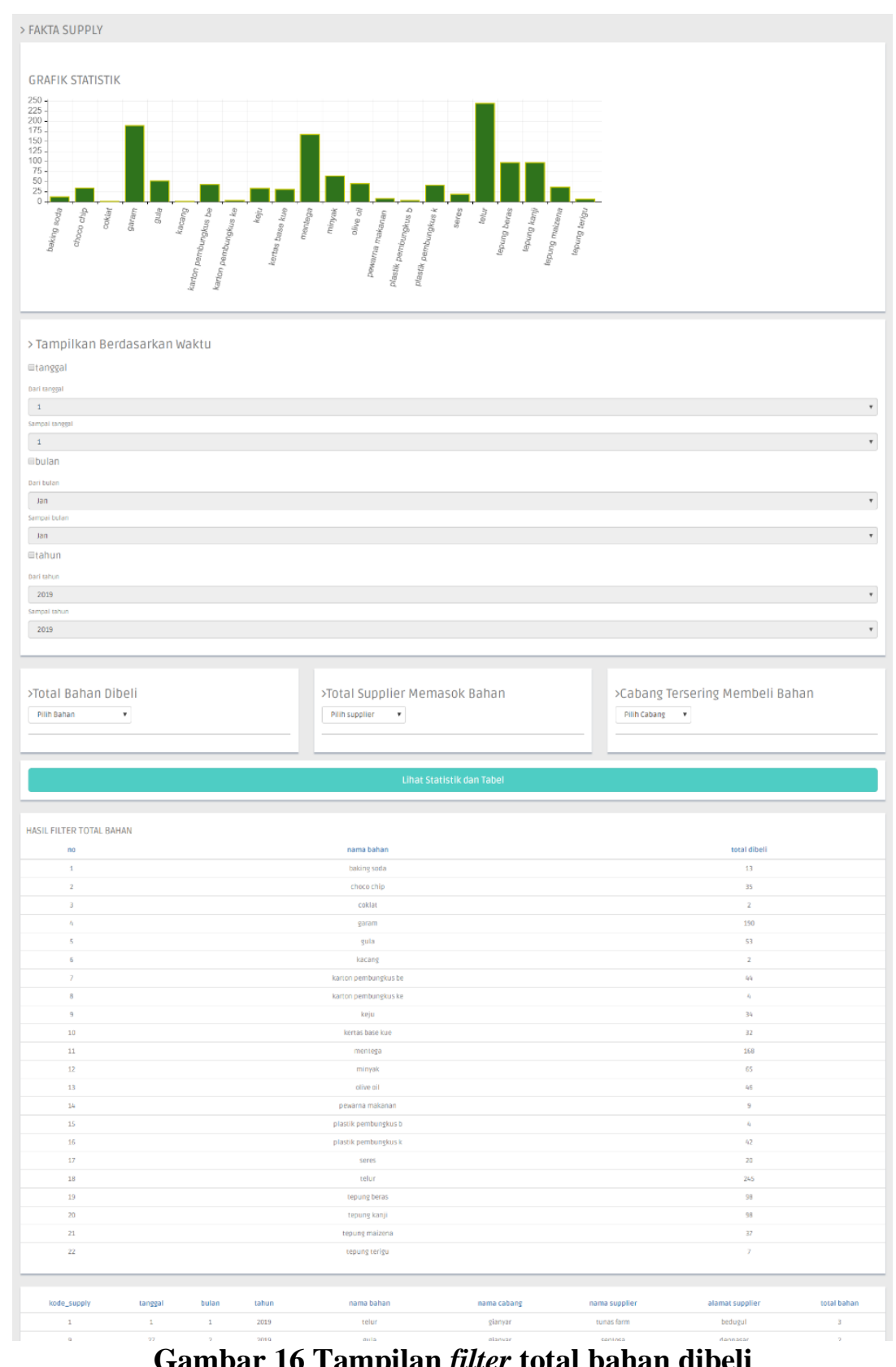

Gambar 16 merupakan tampilan filter total bahan dibeli berdasarkan filter waktu bulan Januari hingga Desember. Terdapat juga dua filter lainnya yaitu total supplier memasok bahan dan cabang tersering membeli bahan, ketiga filter dapat juga digabungkan dengan filter waktu sesuai dengan kebutuhan analytical. Ketiga fitur filter pada olap pembelian ini jika sudah menekan tombol 'lihat statistik dan tabel' akan menampilan dalam bentuk grafik pada bagian atas dan dalam bentuk tabel pada bagian bawah filter. 


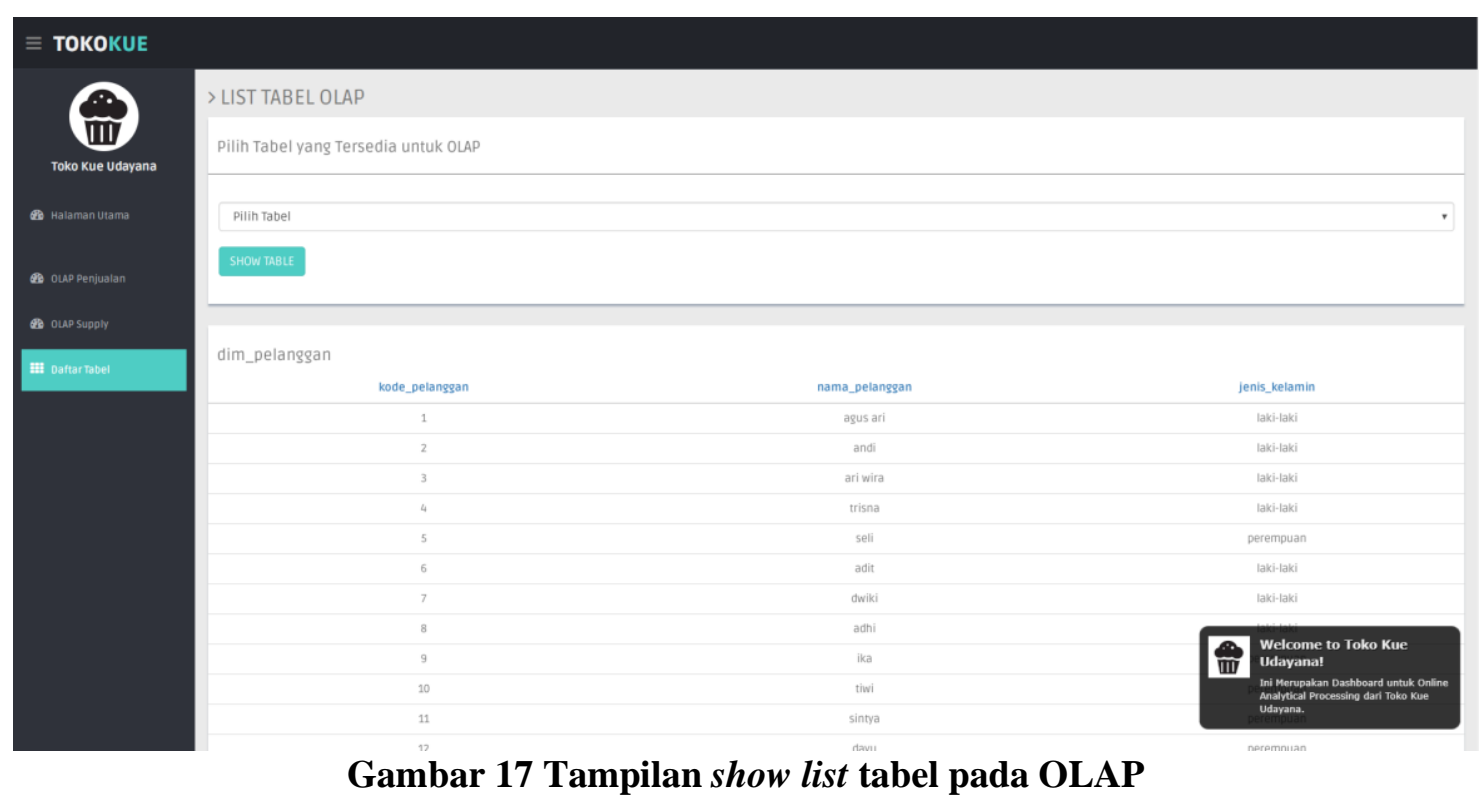

Gambar 17 merupakan tampilan show list tabel pada OLAP yang menampilkan tabel dimensi yang ada pada database OLAP. Pada tampilan ini dapat menampilkan isi dari tabel setiap tabel dimensi yang dipilih.

\section{KESIMPULAN}

Hasil implementasi dan pengujian sistem yang telah dilakukan dalam penelitian ini dapat disimpulkan bahwa dengan menggunakan engine ETL yang bisa bekerja secara manual atau otomatis dapat mempermudah manajemen level atas dalam mengambil keputusan. Apalagi engine ETL yang dibangun sudah dilengkapi dengan fitur cleansing data, dimana sangat penting adanya fitur ini untuk meminimalisir adanya salah input oleh user. Untuk mempermudah pada proses ETL, rancangan engine ETL sudah dilengkapi juga dengan fitur metadata, dimana fitur ini berfungsi untuk mengetahui informasi tabel yang ada untuk mempermudah user technical metadata. Engine ETL yang dibangun sudah mampu melakukan proses extract, transform dan load dari database OLTP menuju database tujuan data warehouse dan juga dapat menampilakan riwayat atau history proses yang sudah dilakukan engine ETL. Tampilan OLAP yang dibangun pada penelitian ini sudah mampu menampilkan grafik pembelian dan penjualan toko kue berdasarkan tabel yang ditampilkan dengan menggunakan filter waktu, filter jenis kue, filter cabang, filter pelanggan, dan filter supplier. 


\section{REFERENSI}

[1] T. Baibul, "ANALISIS DAN PERANCANGAN DATA WAREHOUSE PERPUSTAKAAN (STUDI KASUS: PERPUSTAKAAN UNIVERSITAS BINADARMA PALEMBANG," Semin. Nas. Inform. 2013 (semnasIF 2013) UPN "Veteran" Yogyakarta, 18 Mei 2013, 2017.

[2] D. Edi and S. Betshani, "Analisis Data dengan Menggunakan ERD dan Model Konseptual Data Warehouse," J. Inform., 2012.

[3] I. W. S. Pramana, P. R. Iswardani, and P. A. Mertasana, "IT Governance Evaluation of Hotel Warehouse Section Using the COBIT 5 Framework," Int. J. Eng. Emerg. Technol., vol. 3, no. 2, pp. 5-12, 2018.

[4] A. . N. Narendra, S. I. Murpratiwi, and M. Sudarma, "Design of E-Grant Application Data Warehouse," Int. J. Eng. Emerg. Technol., vol. 2, no. 1, p. 11, 2017.

[5] P. R. Iswardani, I. W. S. Pramana, and K. O. Saputra, "Design of Data Warehouse for Monitoring Hotel' s Food and Beverage Cost," pp. 1-4.

[6] Y. Oslan and H. Kristanto, "Proses ETL (Extract Transformation Loading) Data Warehouse untuk Peningkatan Kinerja Biodata dalam Menyajikan Profil Mahasiwa dari Dimensi Asal Sekolah," Res. Fair Unisr, vol. 3, no. 1, 2016.

[7] M. P. Ambara, M. Sudarma, and I. N. S. Kumara, "Desain Sistem Semantic Data Warehouse dengan Metode Ontology dan Rule Based untuk Mengolah Data Akademik Universitas XYZ di Bali," Maj. Ilm. Teknol. Elektro, vol. 15, no. 1, p. 8, 2016.

[8] I. M. S. Putra and D. K. T. Adhitya Putra, "Rancang Bangun Engine ETL Data Warehouse dengan Menggunakan Bahasa Python," J. RESTI (Rekayasa Sist. dan Teknol. Informasi), vol. 3, no. 2, pp. 113-123, 2019.

[9] O. Herden, "Data Warehouse," in Taschenbuch Datenbanken, 2015.

[10] R. Kimball and M. Ross, The Data Warehouse Toolkit. Wiley Computer Publishing, 2002.

[11] W. H. Inmon, Building The Data Warehouse. Wiley Computer Publishing, 2002.

[12] L. M. Yulyantari, "Sistem Informasi Eksekutif Data Alumni Perguruan Tinggi Menggunakan Data Warehouse," pp. 18-25.

[13] A. Riezka, I. Atastina, and K. Maulana, "Analisis Dan Implementasi Data-Cleaning Dengan Menggunakan Metode Multi-Pass Neighborhood (Mpn),” 2011.

[14] D. Dharmayanti, A. M. Bachtiar, and A. Heryandi, "PEMODELAN DATA WAREHOUSE," vol. 12 , no. 2, pp. 151-168.

[15] I. Tresnawati, E. Susilowati, D. Warehouse, and S. Schema, "PADA SISTEM PENGOLAHAN," no. November, pp. 1-7, 2014. 